\title{
Percutaneous treatment of liver metastases
}

\author{
Joseph P Erinjeri \\ From International Cancer Imaging Society Meeting and 15th Annual Teaching Course (ICIS 2015) \\ London, UK. 5-7 October 2015
}

Early detection of metastatic disease within the liver by advanced diagnostic imaging has driven the rise of image-guided intervention for hepatic metastases. In this talk, we will explore the rationale, indications, technique and post procedure imaging findings of percutaneous treatments of liver metastases. Curative intent ablative therapies, such as radiofrequency ablation, microwave ablation, cryoablation, and irreversible electroporation will be discussed, including the common pitfalls of reading post ablative imaging studies. In addition, bridging and palliative therapies embolotherapies for liver dominant metastatic disease, such as hepatic artery embolization, transarterial chemoembolization, drug eluting beads, and yttrium-90 selective internal radiation therapy, will be reviewed.

Published: 2 October 2015

Submit your next manuscript to BioMed Central and take full advantage of:

- Convenient online submission

- Thorough peer review

- No space constraints or color figure charges

- Immediate publication on acceptance

- Inclusion in PubMed, CAS, Scopus and Google Scholar

- Research which is freely available for redistribution 